\begin{tabular}{ll}
\hline 総 & 説 \\
\hline
\end{tabular}

\title{
耳鳴に対する新しい治療法・TRT（療法）
}

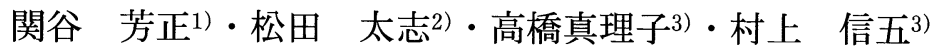 \\ Introduction and Discussion of Tinnitus Retraining \\ Therapy (TRT)
}

\author{
Yoshimasa Sekiya \\ (Sekiya Jibiinkouka) \\ Futoshi Matsuda \\ (Kasugai Municipal Hospital) \\ Mariko Takahashi and Shingo Murakami \\ (Nagoya City University)
}

\begin{abstract}
Although Tinnitus Retraining Therapy (TRT) is becoming very popular all over the world, it is still not well known in Japan. In this paper, we will introduce and discuss the theory and practice of TRT.

TRT is based on the theory of Jastreboff's neurophysiological model, which postulates that a number of systems in the brain are involved in the emergence of Tinnitus and the auditory periphery plays only a secondary role. The purpose of this method is habituation by using low level sound and directive counseling.

Though this therapy is thought to be a powerful methods for Tinnitus, there are some uncertainties regarding the roles of sound and counseling.

Larger scale control studies are nescessary to conform its effectiveness and rationalize the theory.
\end{abstract}

Key words : Tinnitus Retraining Therapy, TRT, sound therapy, directive counseling

耳鳴は耳鼻咽喉科医が日常診療において相談を受ける 最む一般的な症状の一つである. そして治療に関して頭 を悩ますものの一つでもある.

もちろん，さまざまな治療が試みられている，循環改 善剤, ビタミン剤, 抗不安薬, 抗うつ剤, 漢方薬などの 内服薬の投与, キシロカインなどの静注療法, ステロイ ドなどの鼓室内注入, マスカー療法, 耳への電気刺激, 心理療法，バイオフィードバック法，鍼や尒などの東洋
医学的治療法などである.

しかし，効果，手間，副作用などのことを考えるとな かなか有効な治療法を示すことができず,「あまり気にし ないように」とか「耳鳴りとうまく付き合いなさい」と いうことを述べるしかできない場合も少なくはない．

そのようななかで新しい治療法として欧米で急速に普 及しつつある治療法が Tinnitus Retraining Therapy（以下 TRT）である．耳鳴に対する治療法は大きく分けると，

1）関谷耳鼻咽喉科（名古屋市）

2）春日井市民病院耳鼻咽喉科

3）名古屋市立大学耳鼻咽喉科学教室 
耳鳴の発生を根本的に消失, 減弱させる目的のものと, 耳鳴に対する受け止め方や感受性を改善させる目的のも のとがある. TRT は主に後者に属する治療法である.

TRT は 1980 年代後半にJastreboffによって唱えられた 耳鳴の神経生理学的モデルに基づき, 1988 年 Hazell に よって英国ロンドンで, 1990 年に Jastreboff 自身によっ て米国で始められた比較的新しい治療法である (http: //www.tinnitus-pjj.com/origin.html; update May 27, 1998). その特徵は指向性カウンセリング (directive counseling) と, 音, 特にノイズを利用した音治療（sound therapy） を組み合わせることで耳鳴を消失させるのではなく，耳 鳴に対して順応（habituation）を起こさせることを目的 にしている点である.

TRTの有効性は8割前後といわれ，その高い有効性から 欧米では急速に普及してきている治療法である.しかし， 日本においてはまだ非常に限られた施設でしか行われて おらず，またほとんどの耳鼻咽喉科医にその治療法が知 られていないのが現状である. そこでこの論文では TRT の紹介および解説，さらにはいくつかの論点を述べてみ たい.

まず TRT の原理と実際について Jastreboff ら 1) 4) の 論文に拠って述べたい. なお, 詳細は彼らの論文 ${ }^{1)}$ ４) を 参考にされたい。

\section{Jastreboff の神経生理学的モデル}

TRTはJastreboff ら ${ }^{1)}$ の耳鳴に関する神経生理学的モデ ルに従って考え出された治療法である（図 1). 以下彼の 神経生理学モデルについて解説をしていく.

（1）耳鳴の発生源は聴覚路の比較的末梢（螖牛, 聴神 経など）にある。

耳鳴のメカニズムの詳細はいまだに不明であるが，耳 鳴が難聴の人に多いこと，また難聴と一致した周波数の 耳鳴がみられることが多いことからも耳鳴の起源となる 異常な信号が聴覚路の比較的末梢の方で発生しているこ とが推測される.

（2）この信号の異常を皮質下で感じ取る.

われわれは逐次いろいろな感覚を意識することは可能 であっても, 同時に複数のことを認識することはできな い. では体のいろいろな感覚器から入力されてくる膨大 な情報の中からいかにして必要な情報だけを選んでいる のかというと, 1）不必要な情報を意識下で選択し切り捨 て, 意識に上らないようにしている，2）できる限り多く

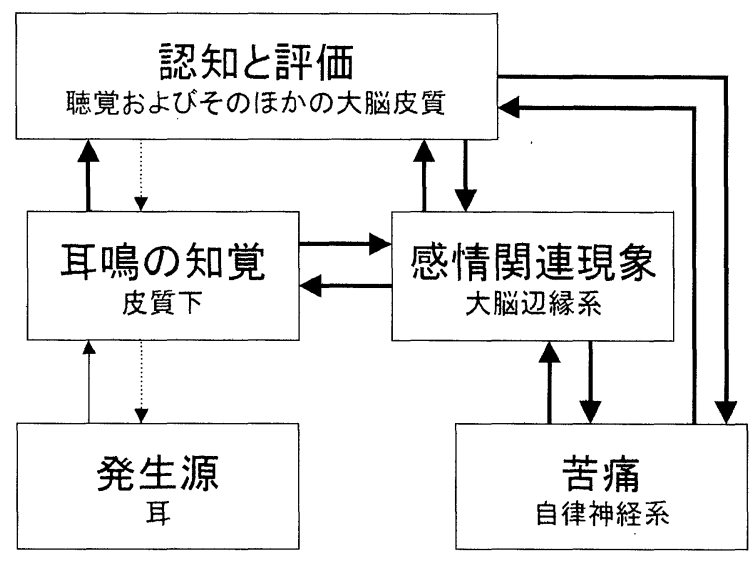

図 1 Jastreboff の耳鳴に関する神経生理学的モデル (Jastreboff PJ, et al. : J Am Acad Audiol 11:162 177, 20001) より)

の情報を無意識に処理できるように自動化してしまう， 3）意識にのせなくてはならない情報は優先順位をつけ る，4）優先度の高いものから認識していくという過程を 経て行われているのである.ここにおいてどの情報を切 り捨て，どの情報を認識するかに関しては過去の経験が 大きな役割を果たしていると考えられている.

たとえば，われわれは家の外を走っている自動車の音 や，家の中の冷蔵庫のファンの音を気にすることはあま りない，一方，赤ん坊の泣き声に対して，親は遠くにい ても気がつくのである．これは末梢（耳）からの音の信 号が皮質下において評価，分類され，その人に重要，必 要と判断された音だけがさらに大脳皮質に達し, 意識に 上っているからである.つまり音の取捨選択が脳で行わ れているのである.ではどんな音が重要と認識されてい るのかといえば，快適な音，有用な音，そして危険を知 らせる音である。

耳鳴も起源は外からではないにしても, ニューロンを 介し脳に到達する時点ではいろいろな音信号の一つでし かない，そのなかで耳鳴を意識するといらことは，皮質 下においてさまざまな音のなかからあえて耳鳴を危険な 音, 注意を要する音として選別してしまっているのであ る.

（3）耳鳴の知覚と評価は脳皮質で行われる.

そして，いったん耳鳴を知覚し，ストレスにさらされ たり, 耳鳴に対してマイナスのイメージ，たとえば脳の 異常や重大な病気の前触れではないかといら恐怖を感じ たり，あるいはほかの人から「耳鳴りは治らない」といっ 
た言葉を聞くことで，ますます耳鳴に過敏になってしま らのである。それはちょうど，アパートの隣の家から 「ギーギー」といら物音が聞こえてくると, 何か犯罪が起 きているのではないかと考光てしまい，その音が耳から 離れなくなってしまうのと同じことある. (実際は子供が バイオリンの練習をしているのであるが.）

（4）さらに大脳辺縁系（情緒）と自律神経の活性化が 起き, 耳鳴の悪循環が起きる.

耳鳴に対してマイナスのイメージを抱いてしまうと情 緒と関係の深い大脳辺縁系が刺激され，不安，不快，恐 怖，苛立ちなどの気分が生じる．すると耳鳴に関する感 受性が高まり，音を認識するにあたり優先順位の高いと ころに耳鳴の信号が位置してしまうょうになるのであ る.さらに, 大脳辺縁系が自律神経系を刺激することで 自律神経の失調が起き, 耳鳴に対する不快は一層高まっ てしまうのである.

こうして耳鳴に対する悪循環が起きてしまうのであ る。つまり気にすることにより大脳辺縁系が刺激されて 耳鵬に対する感受性が立進してしまい，またさらに自律 神経系の変調が引き起こされてしまう，そしてそのこと が一層不安を増強させ耳鳴を苦痛なものと感じてしま い，神経や意識がますます耳鳴に集中してしまうように なるのである。

この耳鳴の悪循環こそが問題なのである.

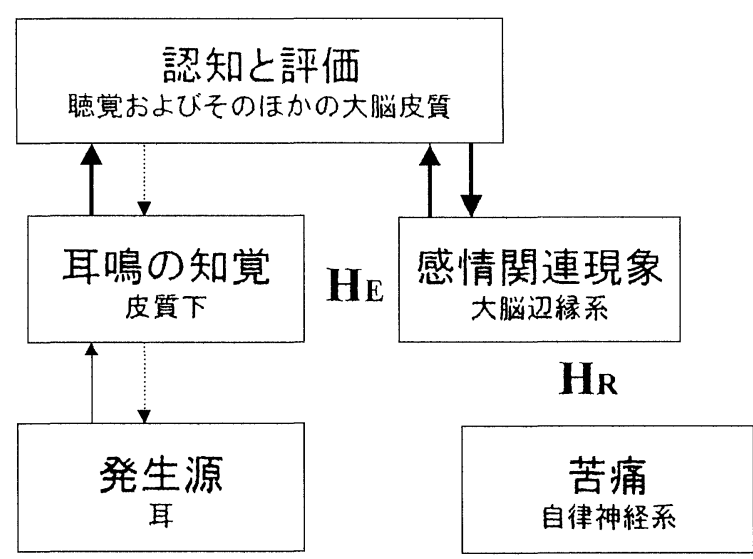

大脳辺縁系と自律神経系における順応

\section{2. 治療の原理}

現在のところ耳鳴をその発生から確実に消失（治瘉） させる根本治療はみつかっていない，しかし，耳鳴が あってもそれを意識しなければよいのである。そこで脳 の高い可塑性を利用し, 耳鳴の信号に対して順応 （habituation）を起こさせる方法が考え出された. TRT は その順応を起こす治療法である. Jastreboff の神経生理学 的モデルによれば，耳鳴には前述のように大脳辺縁系が 梁く関与していると思われている. しかし大脳辺縁系に 直接働きかけることはできない，そこでカウンセリング により耳鳴への理解を深め, その対処方法を学び不安を 取り除くことで意識（大脳皮質）から大脳辺縁系へ働き かける一方, 耳から雑音を与えることにより耳鳴の信号 のコントラストを減弱させ, 大脳辺縁系における耳鳴に 対する過敏性を減らすように働きかけるのである.

このようにして大脳辺縁系をはさんでその下位と上位 から作用することで順応がもたらされるのである(図2).

\section{TRT の実際}

（1）治療のための患者のカテゴリー分類

Jastreboff $ら^{11}$ は患者を聴覚過敏や難聴, 生活への影響 度により 5 つのカテゴリーに分けている（表 1$).$

カテゴリー 0 は, 聴覚過敏もなく難聴の軽度なタイプ で，比較的日常生活で耳鳴による障害を受けていない群 である。この群ではカウンセリングをするだけで積極的

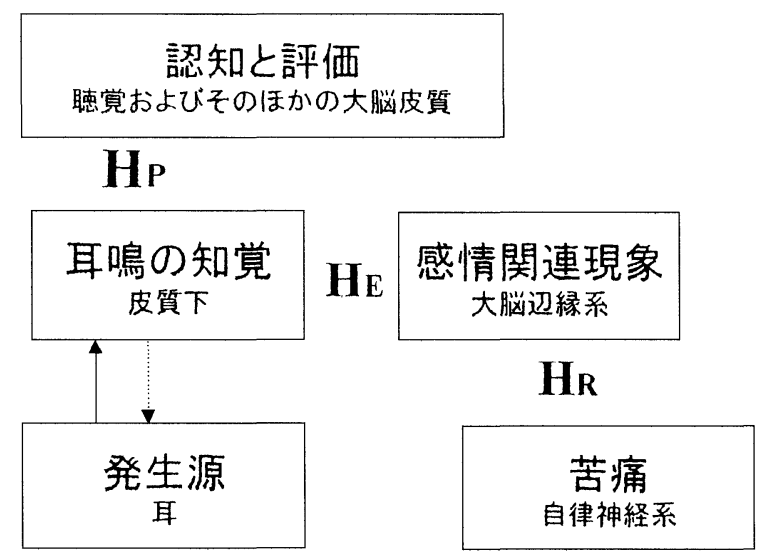

知覚での順応

（耳鳴は意識しない限り聞こえない）

図 2 Jastreboff による順応のレベル

(Jastreboff PJ, et al. : J Am Acad Audiol $11: 162 \sim 177,2000^{1)}$ より)

HR は自律神経系の反応における順応，HE は大脳辺縁系を含む感情的反応での順応，HP は知覚での順応。 
な音治療は行わずに静惄を避け, 音が常にあるような環 境を作るよう勧めるだけである. 耳鳴発症から 2 カ月以 内の人などにはまずこのカテゴリー0の治療を試みるべ きである、静寂を避けるときの音として Hazelli5) はテレ ビなどの音はふさわしくなく, 波の音, 水の音, 換気扇 の音などが最良であると述べている.

カテゴリー 1 は, 難聴は軽度であるが耳鳴に悩んでい る患者が対象である.ノイズジェネレーターを使用して 治療する．ほとんどの患者はこのカテゴリーに属する.

カテゴリー 2 は比較的高度の難聴があり, 補聴器をつ けざるを得ない患者が対象である. 背景音に富んだ場所 での補聴器の使用を勧める. この場合の補聴器の主目的 は音を大きくして背景音を聞くことであって, コミュニ ケーションの改善は 2 次的なものである.

カテゴリー 3 には聴覚過敏の患者が入り, 耳鳴の有無 とは無関係である. 長時間の音の懪露に耐えられない人 が対象となるためノイズジェネレーターは聴覚間值より わずかに大きな音から始め, 次第に音を大きくし脱感作 をしていく.

カテゴリー 4 は, 音を聞くことにより耳鳴や聴覚過敏 が増覀してしまう最も難しいタイプで, まず聴覚閾值か ら音を出し，その後は非常にゆっくりと音量を上げてい く. 音以外にも過敏なことが多いため, 最初は音を出さ ずに単にノイズジェネレーターを装着することだけから 開始することが必要な場合もある.

（2）カウンセリング方法

TRT のカウンセリングは指向性カウンセリング (directive counseling) と称していて指導, 教育的な色合いの強
いものである. 患者に対して, 聞こえの仕組みなどを説 明した後, Jastreboff の理論に基づく耳鳴のメカニズムと 対応の仕方を説明する.

(3) 使用器具

TRT における音治療のノイズの発生源としてノイズ ジェネレーターが使われる，ノイズとしては一般的には ホワイトノイズが使われるが, 最近ではピンクノイズや スピーチノイズなども使われることがあるため, ワイド バンドノイズとも表現されている．よく使われ，かつ Jastreboff ら ${ }^{1)}$ にも推奨されているノイズジェネレーター の一つである Silent Star（Viennatone/ スターキージャパ ン）を例にとると，ちょうど耳掛け型（BTE）の補聴器 の形をしている．原則としてはオープン型のイヤーモー ルドを作って使用するが，付属の耳栓でも十分使用でき る.この耳栓は特殊な形をしており，底に穴のあいた U 字型の耳栓の側面にノイズジェネレーターからのチュー ブが接続されていることで耳を塞ぐことなく外界からの 音と装置からのノイズの両方が同時に耳に入るように なっている. なお，ノイズジェネレーターとしては耳掛 形以外にも耳穴形のものも開発され利用されてきてい る.

ノイズジェネレーターは原則として両耳で 1 日 6 時間 以上の使用が勧められている．また音の大きさは耳鳴が 消えない程度にし，あまり小さな音にしすぎないほうが よいとされている (図 3). 注意しなくてはならないこと はノイズを大きくしすぎて耳鳴がマスクされてしまわな いようにすることである. マスクされてしまうと耳鳴に 対しての順応が起きなくなってしまらからである.

表 1 Jastreboff による耳鳴患者のカテゴリー分類（Jastreboff PJ, et al. : J Am Acad Audiol $11: 162 １ 77 ， 2000^{11) よ り ） ~}$

\begin{tabular}{|c|c|c|c|c|c|}
\hline カテゴリー & 聴覚過敏 & $\begin{array}{l}\text { 章曝露による } \\
\text { 䭪覀 }\end{array}$ & 自覚的難聴 & 生活困難度 & 治療（カウンセリングと豊かな背景音に加え） \\
\hline 0 & - & - & - & 低い & カウンセリングと日常生活では静寂を避け背景音を出す \\
\hline 1 & - & - & - & 高い & ノイズジェネレーターの使用（耳鳴よりわずかに小さく） \\
\hline 2 & - & - & 有 & 高い & 背景音のあるところでの補聴器の使用 \\
\hline 3 & 有 & 無 & 無 & 高い & $\begin{array}{l}\text { ノイズジェネレーターの音を聴力閾值より少しだけ大きく } \\
\text { 設定 }\end{array}$ \\
\hline 4 & 有 & 有 & 無 & 高い & $\begin{array}{l}\text { ノイズジェネレーターの音は聴力閾値と同じぐらいから始 } \\
\text { め, ほんの少しずつ大きくしていく }\end{array}$ \\
\hline
\end{tabular}

聴覚過敏 : 周囲の音に関しての異常な感受性, 特に $100 \mathrm{~dB}$ 以下の不快閾值の場合.

音曝露による増悪：音による耳鳴や聴覚過敏の増悪が翌日まで長時間続く場合.

自覚的難聴 : 患者自身によって生活に問題を感ずる難聴.

生活困難度 : 耳鳴や聴覚過敏により生活に支障をきたす程度.

治療 : 各項目にカウンセリングと豊富な音による背景音の治療と処置を含んでいる. 


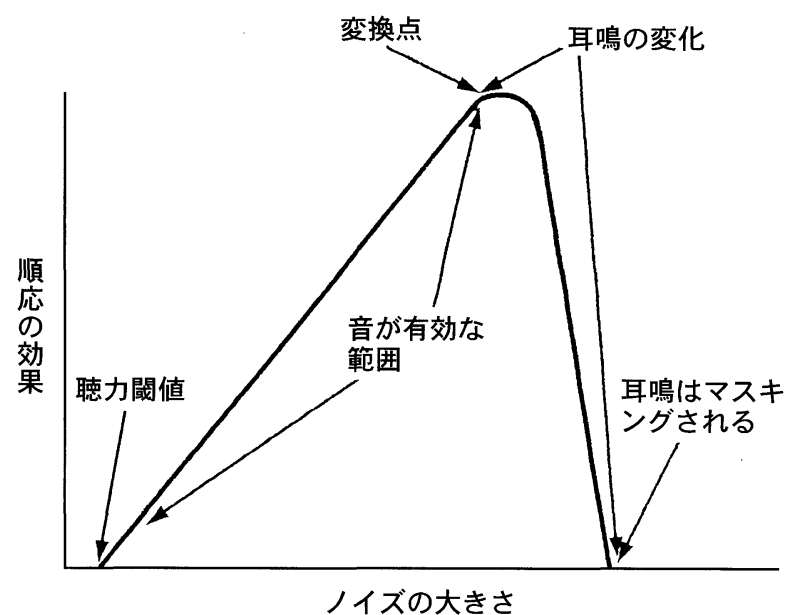

図 3 Jastreboff による TRT におけるノイズの大きさと順応の 効果

(Jastreboff PJ, et al. : J Am Acad Audiol 11:162 177, 20001) より)

最も効果的な音は耳鳴より少し小さな音

表 2 マスカー療法と TRT における音治療の違い

\begin{tabular}{|c|c|c|}
\hline & TRT & マスカー療法 \\
\hline 使用ノイズ & 主にホワイトノイズ & 主にバンドノイズ \\
\hline ノイズの周波数 & 耳鳴とは無関係 & $\begin{array}{l}\text { ピッチマッチで耳鳴 } \\
\text { と合わせる }\end{array}$ \\
\hline ノイズの大きさ & $\begin{array}{l}\text { 耳鳴が消えない大き } \\
\text { さ }\end{array}$ & 耳鳴が消える大きさ \\
\hline 使用時間 & 6 時間以上 & $2 \sim 3$ 時間まで \\
\hline 効果の原理 & 順応 & 遮蔽効果, 後抑制 \\
\hline 作用部位 & 脳, 特に大脳辺縁系 & 比較的末梢 \\
\hline 効果の発現 & 数カ月が必要 & 即効的 \\
\hline 効果の持続 & 永続的 & 比較的短い \\
\hline 不適応 & 特になし & $\begin{array}{l}\text { 耳鳴が遮蔽できない } \\
\text { 場合 }\end{array}$ \\
\hline
\end{tabular}

なお，マスカー療法との音治療の違いをまとめると 表 2 のようになるが, 最も異なる点は使用する音がホワ イトノイズであること, 耳鳴が消えない程度の比較的小 さな音量で聞くことである. なお，マスカー療法の効果 の持続期間は短期としたが，耳鳴をコントロールできる といら自信から，耳鳴による苦痛の持続的な軽滅につな がることは当然ありうることである.

\section{TRT の有効性}

TRT は比較的新しい治療法のため, 有効性に関する報 告は決して多くはない. Jastreboff ら ${ }^{4)}$ の報告ではカウン
セリングとノイズジェネレーターの使用により $80 \%$ で著 明改善がみられたとしている.また 1999 年の第 6 回国際 耳鳴セミナーでは McKinney ら6) はカテゴリーとノイズ の大きさに分けて報告しているが, カウンセリングだけ の群 $(\mathrm{n}=52)$ では $69.8 \%$, カウンセリングとノイズジェ ネレーターで比較的大きなノイズを出した群 $(\mathrm{n}=36)$ で は 83. 3\%の有効率であったと報告している. なお，この とき小さなノイズ音を使用した群 $(\mathrm{n}=36)$ の場合は 66.7 \%の有効率しかなかった. Sheldrake ら ${ }^{7)}$ は 224 名の患者 に対して平均 18 カ月後の最終診察時で $93.7 \%$ が有効で あったと報告している. Heitzmann ら ${ }^{8)}$ は 47 名に対し 84 \%, Herraiz ら ${ }^{9)}$ は 172 名に対し 88\%に有効であったと 報告している. 同セミナー以外の報告としては, Bartnik ら ${ }^{10)}$ は 108 名に対して難聴のない患者では $70 \%$, 難聴の ある患者では $90 \%$ で有効であったとしている.

また，日本では今のところ松田ら ${ }^{1112)}$ のノイズジェネ レーターを使用したTRTの治療成績しか報告されていな いが，6カ月以上治療を続けた群では $90 \%$ 以上，また面 倒くさい, 装置をつける気がしなかったなどの理由で数 日で中止してしまった例を含めても $70 \%$ 以上で耳鳴に対 する改善がみられた。

ここでわれわれの治療経験からどのような経過で効果 が出てくるのかを述べてみる．個人差は大きいのである が，一般的には，開始後 1カ月ほど経過した時点でノイ ズジェネレーターをつけている最中は耳鳴を少し楽に感 じるようになり，3カ月ほど経過した時点から「耳鳴りに 慣れてきた」と感ずる．そして 1 年ほど経過した時点で 「明らかに耳鳴りが以前に比べ気にならなくなっている」 ことに気づき， 1 年半ほど経過した時点でノイズジェネ レーターの使用を次第に忘れる，あるいは使用しないで もすむようになる。

TRT自体は耳鳴を小さくしたり消失させることが目的 の治療ではないが, 1 年ほど経過した時点で耳鳴が小さ くなったと感ずる場合も多くみられる．おそらく，順応 が得られた結果, 意識としては耳鳴の音が小さく感じら れるようになったのであろう. 実際に耳鳴のラウドネス 検查をしても治療前後で違いが認められない場合が大半 である．なお，ホワイトノイズ自体がマスカー療法で使 われる狭帯域雑音に比べ比較的聞きやすい音であること と, 耳鳴が消えない程度の小さな音で聞くこと,さらに 器具を装着していても耳栓に孔が開いているため耳を塞 ぐことがなく外部の音もそれまでどおりに聞こえ, 装着 
による不快感はほとんどなく, 大半の患者においては装 用に際して我慢を必要とはしない.

\section{TRT に関するいくつかの論点}

Jastreboff ら ${ }^{1)}$ は耳鳴の根治, 消失ではなく耳鳴に対し て反応性の軽減を起こす治療法を THT（tinnitus habituation therapy）と呼んでいる. 脳で耳鳴に対して順応 （habituation）が起きることを目的としているからであ る. それには自律神経訓練法やバイオフィードバック 法, 心理療法, カウンセリング療法, 催眠療法などを含 むとしている，さらに THT のうち指向性カウンセリン グ (directive counseling) と音治療（sound therapy）から 成り立っているものを TRT と位置付けている.

TRTの評価はこのようにカウンセリングの要素と音治 療の 2 つ要素が入り混じっているため一層その評価が 難しいものとなっている. Jastreboff ら1) によればもちろ んその両者が組み合わさることで一層の効果が得られる としているが，はたしてカウンセリングが効くのか音治 療が有効であるのかが疑問となってくるところである.

TRT のカウンセリングを Hazelli) は指向性カウンセリ ングと呼び, Jastreboff の神経生理学的モデルに基づきそ れを患者に説明し納得させることにより耳鳴に対する認 識を正確なむのにし，耳鳴に関する疑問や不安を解消す ることができるとしている. そのカウンセリングの特徴 は相互的というよりもより一方的でむしろ教育的なもの である．またカウンセリングの対象を耳鳴に限局し，患 者の生活や思想にまでは踏み込まない点も特徴である. このとき治療に用いる耳鳴モデルは, Jastreboff の神経生 理学的モデルに基づいたものを使用し，ほかのものはと きに患者に誤解や疑念を起こさせてしまう可能性がある ため使用すべきではないとしている51.

しかしこのカウンセリングを Wilson ら ${ }^{13)}$ や KroenerHerwig ら ${ }^{14)}$ は認知療法にしか過ぎず,かつ認知療法とし ては不十分なものであるとし，耳鳴における脳の役割は 以前より認知療法において認められてきたことでTRTで 新たに付け加えられた概念ではないと批判している. な 打認知（行動）療法は悪循環に陥った間違った考え方を カウンセリングにより正しい考え方や判断に戻す治療法 で，うつ病をはじめパニック障害, 対人恐怖など広い範 囲に応用されている ${ }^{15)}$. また慢性疼痛などの特定の症状 に対してもそれぞれに専用化した認知療法が行われるこ とがある16)。
それに対して Jastreboff ${ }^{17)}$ は TRT のカウンセリングに 認知療法的な要素が入っていることは認めながらも, 認 知療法が患者との共同作業的な治療で間違った考えを建 設的な考えに訂正し，関心を他のものに移したり，リラ クゼーション法を使用したりして耳鳴そのものよりも感 情, 意識, 社会的な関心を改善することが主眼であるの に対し，TRT は耳鳴そのものを対象とし，耳鳴の背景と なる信念を変えることが目的ではないため，頻回のカウ ンセリングは必要としないと反論している.

一般的に認知療法は専門の知識とトレーニングを受け た精神科医やカウンセラーによって行われるのに対し， TRTのカウンセリングは特別な心理療法の知識がなくて もある程度その治療原理を理解した耳鼻咽喉科医や言語 聴覚士，看護婦であれば実施は可能である，なぜなら患 者との複雑な心理的交流を特に必要としないからであ る.

しかし，TRT は耳鳴に限った認知療法で，その手段と して音を使用したと考えられなくもなく，言葉の定義上 の問題にしか過ぎないのかもしれない.

またカウンセリングにおいてJastreboffの神経生理学的 モデルが正しいものであるのか証明されていない時点 で,それを絶対視していることにも疑問が呈されている. その理論が正しいとしてもカウンセリングの効果がはた して彼のモデルを使用したことによるものなのか，ある いは他のもっともらしい理論を患者に呈示しても同様の 効果が得られるのではないかといら疑間も呈されてい る.つまり TRT の効果は強い期待と権威に裹付けられた 説明と本質的に耳鳴は無害であるということを保証され ることによるのではないかといらものである ${ }^{18)}$.

音治療に関してもそれがどのようにどの程度有効であ るのかまだ議論の多いところである. McKinney ら ${ }^{199}$ は カウンセリングだけの群とさらにノイズジェネレーター を使用した群, 補聴器を使用した群で比較し, 差がなかっ たと報告している. また Haerkotter ら ${ }^{20)}$ の検討ではノイ ズジェネレーターの使用が 4 週間だけと短かったことも あり，ノイズジェネレーターを使用した群としなかった 群とで差がなかったと報告している。一方 Schneider $ら^{21)}$ の耳鳴のため日常生活を送ることが困難な患者に対 するトライアルでは，ノイズジェネレーターを使用しな いコントロール群で $4 \%$ では生活に困難を感じなくなっ たとしているのに対し，使用した群では $31 \%$ であったと 報告している. 
TRT の音治療として, 1) 特別な器具は使用しないで静 寂を避ける，2）ノイズジェネレーターを使用する，3） 補聴器を使用する, の 3 つの方法が述べられている。 し かし, 雑音の面からも実行面でも, そして心理面でもこ の三者の間では大きな違いがあるように思われる. 現在, これらの治療をまとめてすべて TRT としているが, 全く 同じ意義と考えてよいのか検討を要する必要がある.

さらにノイズの種類や大きさをどのように設定するの かといら問題がある. Jastreboff ら ${ }^{1)}$ はノイズの大きさを 耳鳴が消えない程度の大きさが最適で, あまり小さな音 ではかえって音に対する反応性が立進してしまい, 逆効 果であるとしている. しかし, 最も有効なノイズの大き さに関して今のところ McKinney ら ${ }^{22)}$ の報告以外にデー タとしてはほとんど出されていない. また，使用するノ イズも多くの場合ホワイトノイズが使われているが，ほ かの音ではいけないのか，あるいはもっと有効な音はな いのかということに関しての検討もされてはいない. ま た, Jastreboff ら ${ }^{1)}$ はノイズジェネレーターを両側性の場 合はもちろん一側性の耳鳴であっても両耳に使用するよ ら勧めているが，そのことに関する検証もされてはいな 认.

さてここまで述べてきたように，TRT の効果に関して はある程度認められてきているが，その有効性の評価と 解釈に関してはまだまだ検討されなくてはならないこと が多いように思われる. TRT はその治療法の性質上, 薬 物療法の場合のような完全な比較試験をすることは不可 能と思われるが，できることならば何らかのコントロー ルをおいた大規模な検討が行われるべきであり，そこで TRTの効果をカウンセリングと音治療のそれぞれについ て検討する必要性があるように思われる.

\section{まとめ}

TRTが欧米でこれほど急速に広まりつつあるのはそれ なりの効果が患者, 治療施行者に認められているからで ある.しかし，まだまだ検討されなくてはならない問題 は多い.

TRTのカウンセリングと音治療を組み合わせることで 耳鳴に対して順応をもたらすという考え方は，耳鳴治療 における新しい視点と可能性を示すむのと思われる．特 にマスカー療法と違い, 耳鳴が消失するほど大きな音で なくても小さな音を長時間聞くことが効果的であること が示唆されたことは，これからの耳鳴の研究や臨床に新
しい道を開くものと思われた.

\section{参考文献}

1) Jastreboff PJ and Jastreboff MM : Tinnitus retraining therapy (TRT) as a method for treatment of tinnitus and hyperacusis patients. J Am Acad Audiol $11: 162 \sim$ 177, 2000.

2) Jastreboff PJ, Gray WC and Mattox DE : Tinnitus and hyperacusis. Otolaryngology Head \& Neck Surgery, third edition (ed by Cummings CW, Fredrickson JM and Harker LA, et al.). pp $3198 \sim 3222$, Mosby, St. Louis, 1998.

3) Jastreboff PJ : Tinnitus habituation therapy (THI) and tinnitus retraining therapy (THI). Tinnitus Handbook (ed by Tyler RS). pp $357 \sim 376$, Singular, Iowa, 2000.

4) Jastreboff PJ, Gray WC and Gold SL : Neurophysiological approach to tinnitus patients. Am J Otol 17:236 240, 1996.

5) Hazell JWP : The TRT method in practice. Proceeding VI International Tinnitus Seminar 1999. pp $92 \sim 98$, The Tinnitus and Hyperacusis Center, London, 1999.

6) McKinney CJ, Hazell JWP and Graham RL : An evaluation of the TRT method. Proceeding VI International Tinnitus Seminar 1999. pp $99 \sim 105$, The Tinnitus and Hyperacusis Center, London, 1999.

7) Sheldrake JB, Hazell JWP and Graham RL : Results of tinnitus retraining therapy. Proceeding VI International Tinnitus Seminar 1999. pp $292 \sim 296$, The Tinnitus and Hyperacusis Center, London, 1999.

8) Heizmann T, Rubio L, Carenas MR, et al. : The importance of continuity in TRT patients: results at 18 months. Proceeding VI International Tinnitus Seminar 1999. pp $509 \sim 511$, The Tinnitus and Hyperacusis Center, London, 1999.

9) Herraiz C, Hernandez FJ, et al. : Tinnitus retraining therapy: our experience. Proceeding VI International Tinnitus Seminar 1999. pp $483 \sim$ 484, The Tinnitus and Hyperacusis Center, London, 1999.

10) Bartnik G, Fabijanska A and Rogowski M : Effects of tinnitus retraining therapy (TRT) for patients with tinnitus and subjective hearing loss versus tinnitus only. Scand Audiol Suppl 52 : $206 \sim 208,2001$.

11）松田太志, 関谷芳正, 高橋真理子, 他 : Noise Generator を 用いた Tinnitus Retraining Therapy による耳鳴の治療経験. Audiology Japan $44: 163 \sim 170,2001$.

12）松田太志, 関谷芳正, 高橋真理子, 他:TRT (Tinnitus Retraining Therapy）による耳鳴治療（その 2). Audiology Japan 44 : $505 \sim 506,2001$.

13) Wilson PH, Henry JL, Andersson G, et al. : A critical analysis of directive counselling as a component of tinnitus retraining therapy. Br J Audiol $32: 273 \sim 286,1998$.

14) Kroener-Herwig B, Biesinger E, Gerhards F, et al. : Retrain- 
ing therapy for chronic tinnitus; a critical analysis of its status. Scand Audiol $29: 67 \sim 78,2000$.

15）ジュリアン バター：不安，時々認知療法後心は晴れ（勝 田吉彰訳)。星和書店，東京，1993。

16）岩本隆茂，大野 裕，坂野雄二：認知行動療法の理論と実 際. 培風涻, 東京, 1997.

17) Jastreboff MM : Cogtroversies between cognitive therapies and TRT counseling. Proceeding VI International Tinnitus Seminar 1999. pp $288 \sim$ 291, The Tinnitus and Hyperacusis Center, London, 1999.

18) Ross Coles : An international View-The $6^{\text {TH }}$ International Tinnitus Seminar. Tinnitus Today $25: 14 \sim 15,2000$.

19) McKinney CJ, Hazell JWP and Graham RL : Retraining therapy-outcome measures. Proceeding V International Tinnitus Seminar 1995. pp $524 \sim 525$, American Tinnitus Association, Portland, 1996.

20) Haerkotter $C$ and Hiller $W$ : Combining elements of tinnitus retraining therapy (TRT) and cognitive-behavioral therapy;
Does it work?. An International Proceeding VI International Tinnitus Seminar 1999. pp 399 402, The Tinnitus and Hyperacusis Center, London, 1999.

21) Schneider E, Hocker K, et al. : Does systemic noise stimulation improve tinnitus habituations?. An International Proceeding VI International Tinnitus Seminar 1999. pp $391 \sim 393$, The Tinnitus and Hyperacusis Center, London, 1999.

22) McKinney CJ, Hazell JWP and Graham RL : An evaluation of the TRT method. Proceeding VI International Tinnitus Seminar 1999. pp $99 \sim 105$, The Tinnitus and Hyperacusis Center, London, 1999.

原稿受付：平成13年10月26日

原稿採択：平成14年 1 月16日

別刷請求先：関谷芳正

テ460-0004 名古屋市中区新栄町1-3 日丸名古屋ビ ル 6 階

関谷耳鼻咽喉科 